\title{
Effect of Calcium Phosphate Coating on Polyamide Substrate for Biomaterial Applications
}

\author{
Lucimara C. Bandeira, ${ }^{a}$ Kátia J. Ciuffi, ${ }^{a}$ Paulo S. Calefi, ${ }^{a}$ Eduardo J. Nassar, $*, a$ \\ Jorge V. L. Silva, ${ }^{b}$ Marcelo Oliveira, ${ }^{b}$ Izaque A. Maia,${ }^{b}$ Isabel M. Salvado ${ }^{c}$ and \\ Maria Helena V. Fernandes ${ }^{c}$
}

\author{
${ }^{a}$ Universidade de Franca, Av. Dr. Armando Salles Oliveira, No. 201, 14404-600 Franca-SP, Brazil \\ ${ }^{b}$ Centro da Tecnologia da Informação Renato Archer (CTI), \\ Rod. Dom Pedro I, km 143.6, 13069-901 Campinas-SP, Brazil \\ ${ }^{c}$ Departamento de Engenharia Cerâmica e do Vidro, Universidade de Aveiro, \\ CICECO, 3810, Aveiro, Portugal
}

\begin{abstract}
Um novo material a base de poliamida revestida com fosfato de cálcio foi desenvolvido visando potencial aplicação como biomaterial. O revestimento foi obtido pelo método sol-gel e o fosfato de cálcio foi obtido após contato com solução de fluído corpóreo. A poliamida revestida (antes e depois de contado com fluído corpóreo) foi caracterizada através de análises termogravimétrica e térmica diferencial (TGA/DTA), calorimetria diferencial de varredura (DSC), microscopia eletrônica de varredura (SEM) e espectrometria de reflexão total atenuada no infravermelho com transformada de Fourier (ATR-FTIR). As caracterizações revelaram a formação de fosfato de cálcio com uma espessura menor que $3 \mu \mathrm{m}$, o que proporcionou um aumento no ponto de fusão além de melhorar a estabilidade térmica da poliamida. Após contato com o fluído corpóreo, as interações entre o revestimento e o substrato se mantiveram, e houve formação de fosfatos cristalinos e amorfos na superfície de poliamida.
\end{abstract}

A new type of material from polyamide coated with calcium phosphate was developed aiming to have potential application as biomaterial. Coating was obtained by the sol-gel method and calcium phosphate was obtained after contact with body fluid solution. The coated polyamide (before and after contact with body fluid solution) was characterized by thermogravimetric and differential thermal (TGA/DTA) analyses, differential scanning calorimetry (DSC), scanning electron microscopy (SEM) and attenuated total reflectance Fourier transform infrared spectroscopy (ATR-FTIR). These characterizations revealed that the calcium phosphate coating has a thickness of less than $3 \mu \mathrm{m}$, which resulted in an increase in the melting point and improved the thermal stability of polyamide. After contact with body fluid, the interactions between the coating and the substrate remained, and there was formation of crystalline and amorphous phosphates on polyamide surface.

Keywords: sol-gel, dip-coating, rapid prototyping, polyamide coated with calcium phosphate, biomaterial

\section{Introduction}

The design of novel, inexpensive, biocompatible materials is crucial to the improvement of the living conditions and welfare of the population in view of the increasing number of people who need implants. ${ }^{1}$ In this sense, it is necessary to have processes for the biomaterial

*e-mail: ejnassar@unifran.br production that are affordable, fast and simple to carry out. In this context, some researchers have studied the use of polyamide (PA) for the preparation of biocompatible implants because of its excellent mechanical properties, low cost and easy handling. In fact, PA has already been proven to possess good biocompatibility with various human cells and tissues, probably because of its similarity with the collagen protein in terms of chemical structure and active groups. ${ }^{2,3}$ Moreover, the PA biocompatibility can 
be further improved via synthesis of hybrid materials containing hydroxyapatite (HA), which leads to good cellular responses in vitro. ${ }^{3-5}$

Additive Manufacturing (from American Society for Testing and Materials, ASTM) is a set of technologies employed in the structuring of 3D parts achieved through a computer program. It has been widely used in various areas and for many different applications, with emphasis on the ability of these technologies to recreate various types of human tissues in deinking material by means of magnetic resonance X-ray imaging and by the use of a specialized computer program. Additionally, additive manufacturing has been extensively investigated as a potential tool for the fabrication of bone scaffolds and customized implants with desired and controlled internal architecture. ${ }^{5}$ A very simple and effective PA structure forming $3 \mathrm{D}$ objects can be obtained by additive manufacturing using selective laser sintering (SLS). ${ }^{6}$ This SLS technique enables the rapid and reproducible manufacture of products with precise dimensions and complex structure thanks to the action of lasers that increase the temperature of the material in the powder form to its melting point, at this temperature, the particles coalesce and form layers in two dimensions. ${ }^{7,8}$

The sol-gel methodology is widely employed in the production of glasses, oxides, thin films, and coatings, among others. This process is based on the hydrolysis and condensation of metal alkoxide or semi-metallic precursors, leading to the formation of an inorganic polymer or hybrid material. ${ }^{9-12}$ Moreover, it is well-established in the literature that it is possible to create active sol-gel silicabased biomaterials for use in bone tissue regeneration. ${ }^{13-17}$ It has been reported that $\mathrm{Si}-\mathrm{OH}$ groups ${ }^{18,19}$ induce the formation of apatite in a biomimetic solution. ${ }^{20}$ Indeed, different substrates with distinct geometries can be coated by means of the sol-gel process at room temperature and pressure using the dip-coating technique, which consists in immersing the material directly into the prepared sols. ${ }^{21,22}$

In this context, our proposal is to coat PA prepared by additive manufacturing with calcium phosphate by means of the sol-gel technique, which is a fast and simple chemical process that does not require the use of heat treatment or high pressure. The sols used for coating were prepared with and without phosphate ion, and physical and bioactive properties of composite material were available. The bioactive assays were preformed in simulated body fluid (SBF) solution. The materials were characterized by scanning electron microscopy (SEM), thermogravimetric and differential thermal (TGA/DTA) analyses, differential scanning calorimetry (DSC) and Fourier transform infrared spectroscopy (FTIR).

\section{Experimental}

\section{Substrates}

The substrates used in this work were rectangular slides with dimensions of $75 \times 25 \times 1 \mathrm{~mm}$. They were built in an SLS equipment (50 W RF-excited $\mathrm{CO}_{2}$ laser, wavelength of $10.6 \mu \mathrm{m}$ and laser spot of $450 \mu \mathrm{m}$.) utilizing DuraForm $\mathrm{PA}$ as raw material. The latter is a polyamide 12 (PA 12) powder that contains additives. Both the equipment HiQ Sinterstation model and the powder were supplied by the 3D System Co. (U. K.). The processing parameters were: layer thickness of $100 \mu \mathrm{m}$, laser scan speed of $55 \mathrm{~mm} \mathrm{~s}^{-1}$, laser power of $12-13 \mathrm{~W}$, part bed temperature of $175^{\circ} \mathrm{C}$ and roller speed of $177 \mathrm{~mm} \mathrm{~s}^{-1}$.

\section{Sol preparation}

The sol was prepared by adding $4 \mathrm{~mL}$ tetraethylorthosilicate (TEOS), as $\mathrm{Si}-\mathrm{OH}$ source, $1.0 \mathrm{~mL}$ calcium nitrate ethanolic solution $\left(8.0 \mathrm{~mol} \mathrm{~L}^{-1}\right)$, and $0.13 \mathrm{~mL}$ phosphoric acid $85 \%$ to $32.0 \mathrm{~mL}$ ethanol, under magnetic stirring. After $30 \mathrm{~min}$ of agitation, $2.4 \mathrm{~mL}$ ammonia (as catalyst) ethanolic solution was added to the reaction mixture. For comparison purposes, a sol without phosphate was also prepared. The $\mathrm{Ca} / \mathrm{P}$ and $\mathrm{Ca} / \mathrm{Si}$ molar ratios were 1:0.1 and 1:2, respectively.

\section{Polyamide coating}

After $2 \mathrm{~h}$ of agitation, the sol was deposited onto PA by dip-coating, as described in literature..$^{23}$ The substrates remained in the sols for $20 \mathrm{~min}$, followed by drying at $50^{\circ} \mathrm{C}$ for 1 day.

\section{Simulated body fluid (SBF)}

The SBF solution was prepared in aqueous medium by the addition of the reagents $\mathrm{NaCl}, \mathrm{NaHCO}_{3}, \mathrm{KCl}$, $\mathrm{Na}_{2} \mathrm{HPO}_{4} \cdot 2 \mathrm{H}_{2} \mathrm{O}, \mathrm{MgCl}_{2} \cdot 6 \mathrm{H}_{2} \mathrm{O}, \mathrm{HCl}, \mathrm{CaCl}_{2} \cdot \mathrm{H}_{2} \mathrm{O}, \mathrm{NaSO}_{4}$ and $\mathrm{NH}_{2} \mathrm{C}\left(\mathrm{CH}_{2} \mathrm{OH}\right)$ under stirring. The final $\mathrm{pH}$ was $7.43 .{ }^{24}$

\section{Characterizations}

Scanning electron microscopy (SEM) of the materials was performed in a digital scanning electron microscope JEOL JSM T330A. The samples were coated with a thin gold layer using a sputtering method.

Thermal analyses (TGA/DTA/DSC) were carried out in a TA Instruments SDT Q600 simultaneous DTA-TGA thermal analyzer, in the $25-600^{\circ} \mathrm{C}$ temperature range, 
at a heating rate of $20{ }^{\circ} \mathrm{C} \mathrm{min}^{-1}$ and under air flow of $100 \mathrm{~mL} \mathrm{~min}^{-1}$.

The FTIR absorption spectra were obtained with a Mattson 7000 spectrophotometer with Fourier transform, using the reflectance technique.

\section{Results and Discussion}

\section{Scanning electron microscopy (SEM)}

\section{SEM images of the samples before the in vitro test}

Figures $1 \mathrm{a}$ and $1 \mathrm{~b}$ display the SEM of the PA substrate before coating. The PA surface is not homogeneous, in fact, several particles formed after sintering with laser, and there are pores due to the laser wavelength employed during SLS. Figure 1c corresponds to the micrograph that evaluates the thickness of PA coated with the sol prepared with phosphate $(\mathrm{NcP})$, which has a very small thickness. This is ascribed to the use of the dip-coating technique, which is known to yield films with thickness lower than $1 \mu \mathrm{m}$. Figure 1d

(a)

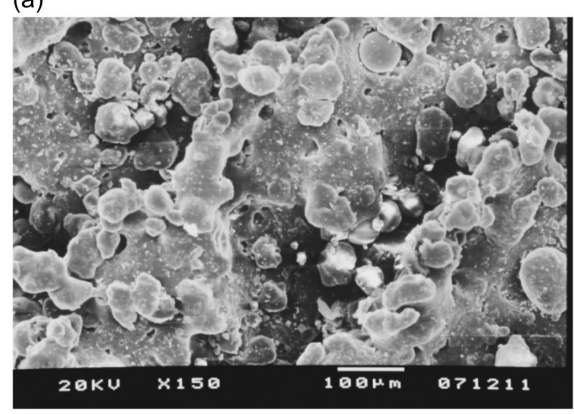

(c)

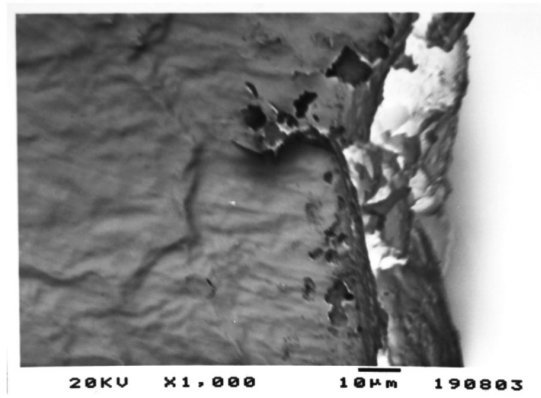

(e)

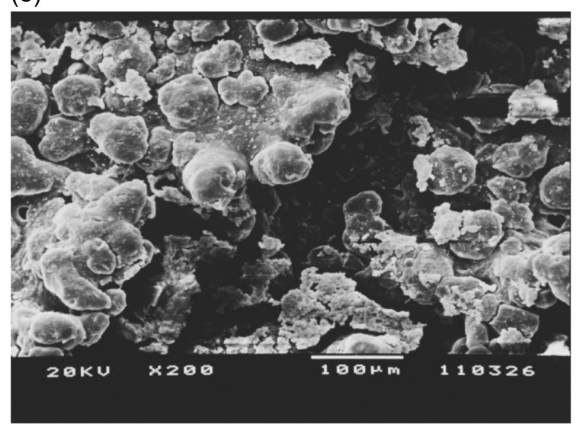

shows the NcP surface, where a homogeneous film with cracks can be noted probably due to the rate of solvent drying. Figures 1e and 1f depict the SEM micrographs of PA coated with the sol prepared without phosphate (NsP). In this case, the film is not homogeneous and consists of agglomerates, contrary to what was observed in the case of NcP. This can be attributed to the fact that the phosphate ion can promote formation of an inorganic polymer in the NcP. This desirable feature enables total coating of the PA substrate and allows its application in biomaterials.

Several works have used polyamide and hydroxyapatite to prepare a biocomposite. ${ }^{25,26}$ In these cases, the authors obtained a porous structure, but the preparation of the materials did not yield a coating. Other works have reported the production of films with calcium chloride and aromatic polyamide containing $-\mathrm{COOH}^{19}$ or polyamide containing sulfonic groups, ${ }^{20}$ and the influence of $\mathrm{Si}-\mathrm{OH}$ groups on the formation of hydroxyapatite was investigated. When these works are compared with ours, the difference is that, in the present work, the sol-gel methodology was used to

(b)

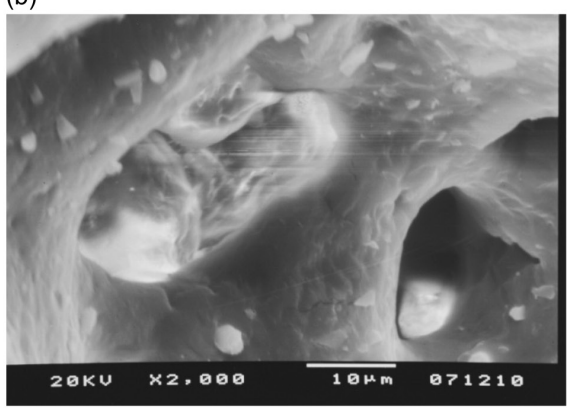

(d)

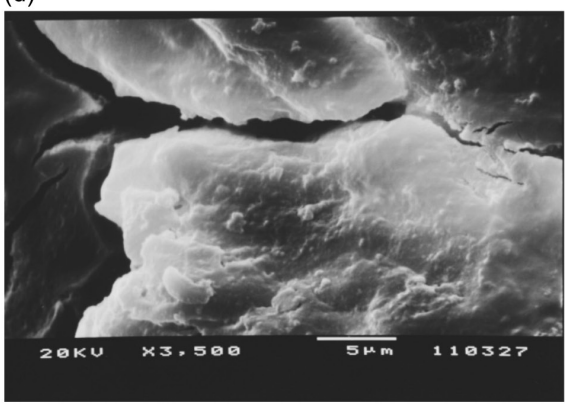

(f)

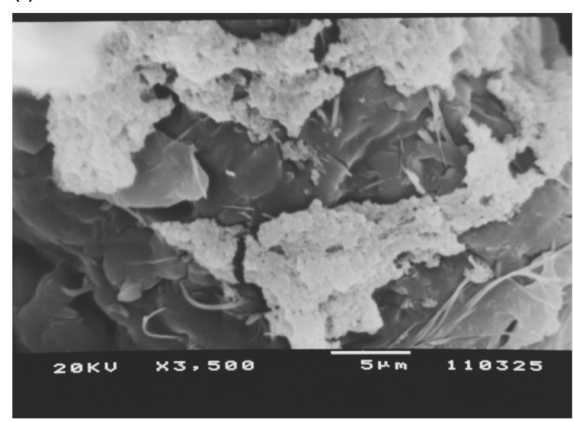

Figure 1. Surface of the PA substrate before coating (a and b) and after coating, thickness of the film in NcP (c), $\mathrm{NcP}$ surface (d) and NsP surface (e and f). 
coat the polyamide piece obtained by rapid prototyping in order to obtain biocompatible materials.

\section{SEM images of the samples after the in vitro test}

Figures 2a, 2b, 2c and 2d display the SEM of the PA substrate after contact with SBF for 15 and 30 days.

After contact with SBF solution, the electronic microscopy clearly showed that the coating was able to interact with the solution and formed crystals in their surfaces. Crystal size increased with larger contact times, and it is expected to be calcium triphosphate and silicate phosphate, such as $\mathrm{Ca}_{5}\left(\mathrm{PO}_{4}\right)_{2} \mathrm{SiO}_{4}$ and $\left(\mathrm{Ca}_{2}\left(\mathrm{SiO}_{4}\right)\right)_{6}\left(\mathrm{Ca}_{3}\left(\mathrm{PO}_{4}\right)_{2}\right)^{27}$ and/or hydroxyapatite. This is as in our previous work, ${ }^{28}$ in which it was observed crystalline phases that were ascribed to hydroxyapatite, using the same synthesis of the present work, but with analysis up to their xerogel.

\section{Thermal analysis (TG/DTA/DSC)}

TGA/DTA/DSC curves of the samples before the in vitro test

Thermal analyses were employed for the identification of probable changes in the thermal properties of the modified materials. Figures $3 a, 3 b$ and $3 c$ present the TGA curves and the corresponding derivates (DTG), DSC and DTA curves for the samples PA, NcP and NsP, respectively.

The DTG and DSC curves reveal that there is a change in the melting point of the PA substrate after coating. PA has a melting point of $185^{\circ} \mathrm{C}$ (Figure $3 \mathrm{a}$ ). Upon coating, its

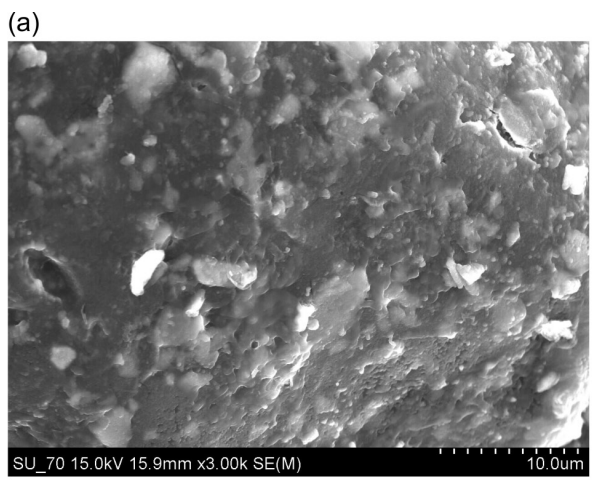

(c)

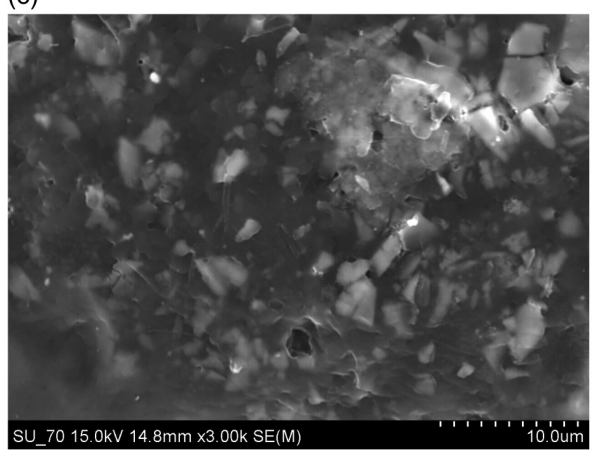

melting point increases to 190 and $194{ }^{\circ} \mathrm{C}$ for the samples $\mathrm{NcP}$ and NsP (Figures $3 \mathrm{~b}$ and $3 \mathrm{c}$ ), respectively. These results indicate that a coating-substrate interaction takes place for both samples. Moreover, the interaction between $\mathrm{PA}$ and the coating in the sample NsP is apparently stronger since the maximum temperature of decomposition observed in Figure $3 c$ is considerably higher. In the literature, there are few works that use the sol-gel methodology to coat a polyamide piece obtained by rapid prototyping. There are also some works that employed thermal analysis and composites or biocomposites. Zhang et al. ${ }^{29}$ studied biocomposites containing different hydroxyapatite (HA)/ polyamide $66(\mathrm{PA})$ ratios and observed that the melting point increases when inorganic materials (HA) are added to the organic compound (PA), being in agreement with our work.

TGA /DTA/DSC curves of the samples after the in vitro test

The NcP and NsP samples were placed in SBF in order to assess the probable bioactivity of the coating. The samples remained immersed in SBF for 15 or 30 days.

After contact with SBF, new thermal analyses were carried out for the samples, demonstrating that the coated PA still presents higher melting points than the non-coated PA. This proves that the interaction between the substrate and the coating is considerably strong, and that the coating does not completely dissolve after the immersion of the samples in the SBF solution. The melting point of the sample $\mathrm{NcP}$

(b)

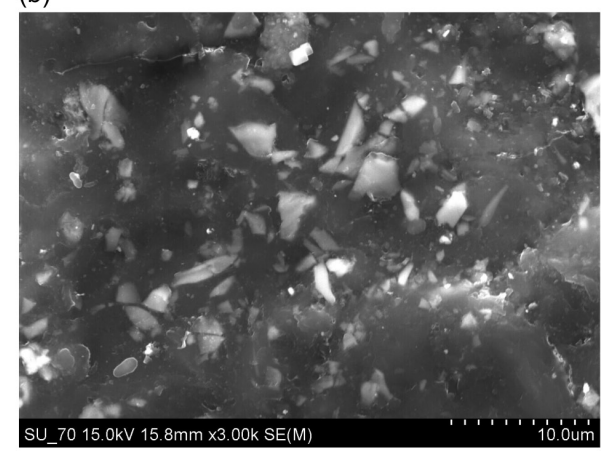

(d)

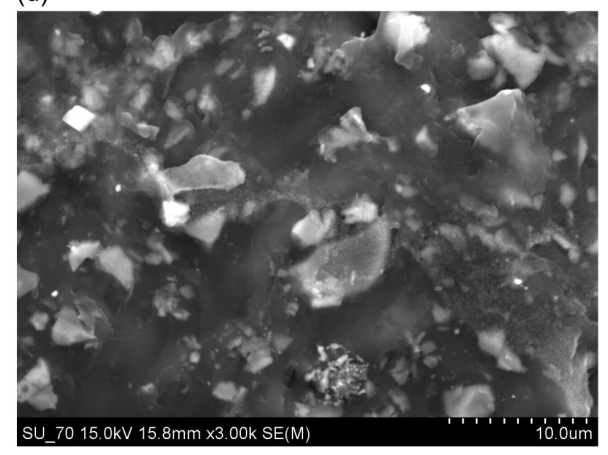

Figure 2. Surface of the PA substrate after contact with SBF (a) NcP 15 days, (b) NcP 30 days, (c) NsP 15 days and (d) NsP 30 days. 

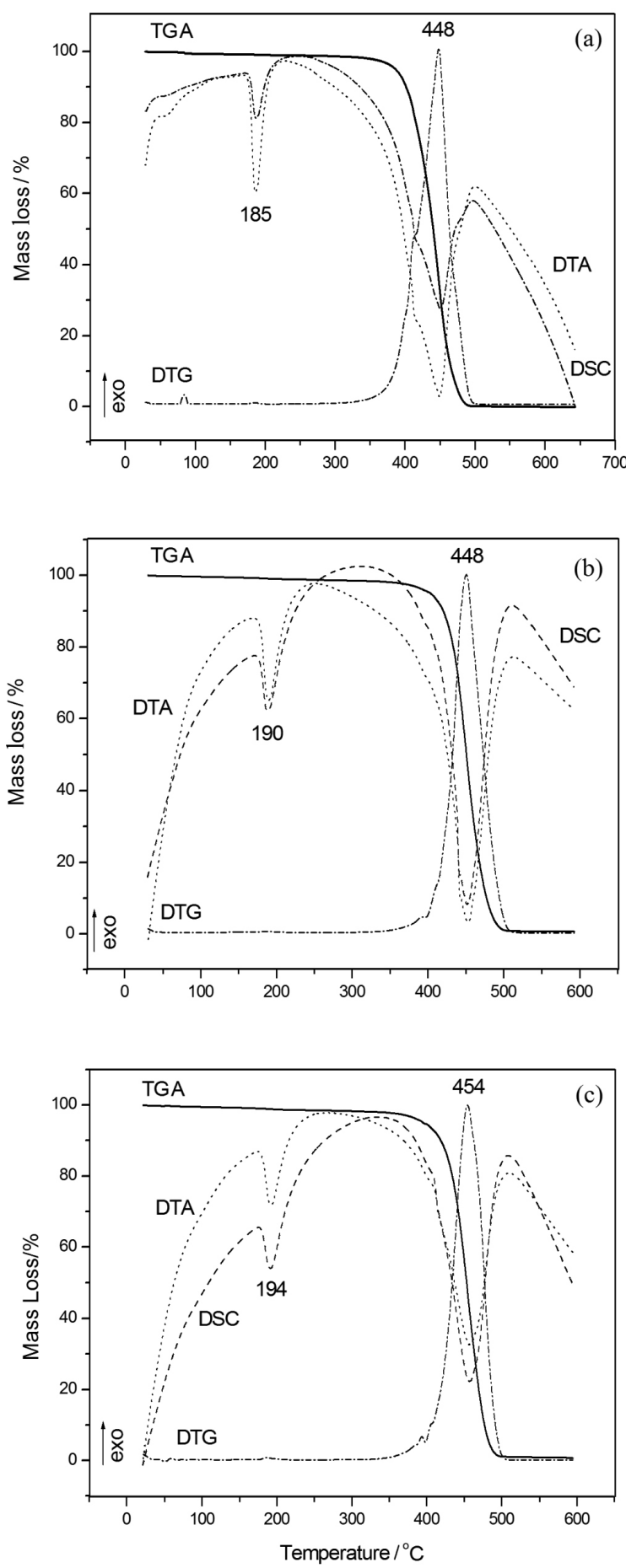

Figure 3. Thermal analyses of $\mathrm{PA}(\mathrm{a}), \mathrm{NcP}(\mathrm{b})$ and $\mathrm{NsP}$ (c).

increases by $5{ }^{\circ} \mathrm{C}$ after 15 days in SBF (Figure 4a) and then decreases after 30 days in SBF (Figure $4 b$ ), but the maximum decomposition temperature is still $4{ }^{\circ} \mathrm{C}$ higher than that of the non-coated substrate. Figures $4 \mathrm{c}$ and $4 \mathrm{~d}$ correspond to the thermal analyses obtained for the sample NsP after 15 and 30 days in SBF solution, respectively. The melting point remains unchanged after 15 days, but after 30 days it decreases, being attributed to the partial dissolution of the coating and it is also detected for NcP.

Attenuated total reflectance Fourier transform infrared spectroscopy (ATR-FTIR)

\section{ATR-FTIR spectra of the samples before the in vitro test}

Figure 5 displays the ATR-FTIR spectra of PA, $\mathrm{NcP}$ and NsP. The spectra evidence changes in the vibration modes of PA upon coating. However, these changes occur in different regions for the $\mathrm{NcP}$ and $\mathrm{NsP}$ samples, indicating that the sols with and without phosphate ions interact with the substrate differently. There is no displacement of the bands assigned to primary amide $\mathrm{C}=\mathrm{O}$ vibration at 1633 and $1542 \mathrm{~cm}^{-1}$, suggesting that the interaction between the substrate and the coating does not take place via this functional group, but that the amide groups of PA are involved in such interaction. The band at $794 \mathrm{~cm}^{-1}$ indicates the presence of $\mathrm{SiO}_{2}$ in the coating. The vibration modes at 3293 and $3090 \mathrm{~cm}^{-1}$ (ascribed to the NH group) and 1059 and $467 \mathrm{~cm}^{-1}$ (assigned to $\mathrm{NH}_{2}$ ) are shifted in the spectrum of NcP compared to the spectrum of PA. These band shifts suggest that there is a weak interaction between these groups and the substrate. ${ }^{2,3}$ As for NsP, the shifts in the bands relative to the amide groups are different from those observed for NcP. The band at $2028 \mathrm{~cm}^{-1}$ in the spectrum of NsP may mean that there are protonated nitrogen atoms forming four bonds, and the appearance of the bands at 1338 and $319 \mathrm{~cm}^{-1}$ could also indicate some variation in the surroundings of the amide groups. Taken together, the FTIR spectral data and the results from thermal analysis suggest that PA-coating interaction in NsP might be stronger compared with the interaction in $\mathrm{NcP}$, probably occurring via hydrogen bonding in the former case. ${ }^{30,31}$

The corresponding wavenumbers of characteristic groups for PA without coating and after coating (namely $\mathrm{NcP}$ and NsP) before contact with the SBF solution are listed in Table 1.

\section{ATR-FTIR spectra of the samples after the in vitro test}

There are clear changes in the FTIR spectra of the coated samples after contact with SBF, as can be observed in Figure 6. The spectrum relative to NcP (Figure 6a) shows that bands identified as being due to the interaction between the coating and the amide groups of the substrate are altered upon contact with SBF. The band at $794 \mathrm{~cm}^{-1}$ corresponding to the presence $\mathrm{SiO}_{2}$ disappears, and the band at $450 \mathrm{~cm}^{-1}$ ascribed to the presence of the $\mathrm{Si}-\mathrm{O}-\mathrm{Si}$ coating is replaced with bands usually relative to the characteristic $\mathrm{C}-\mathrm{C}=\mathrm{O}$ vibrations of the primary aliphatic amide of the substrate at 464 and $420 \mathrm{~cm}^{-1}$. These facts could indicate 
the dissolution of the silica coating. However, the fact that the band at $1064 \mathrm{~cm}^{-1}$ shifts to $1040 \mathrm{~cm}^{-1}$ after 30 days in SBF shows that the $\mathrm{Si}-\mathrm{O}-\mathrm{Si}$ coating is present even after
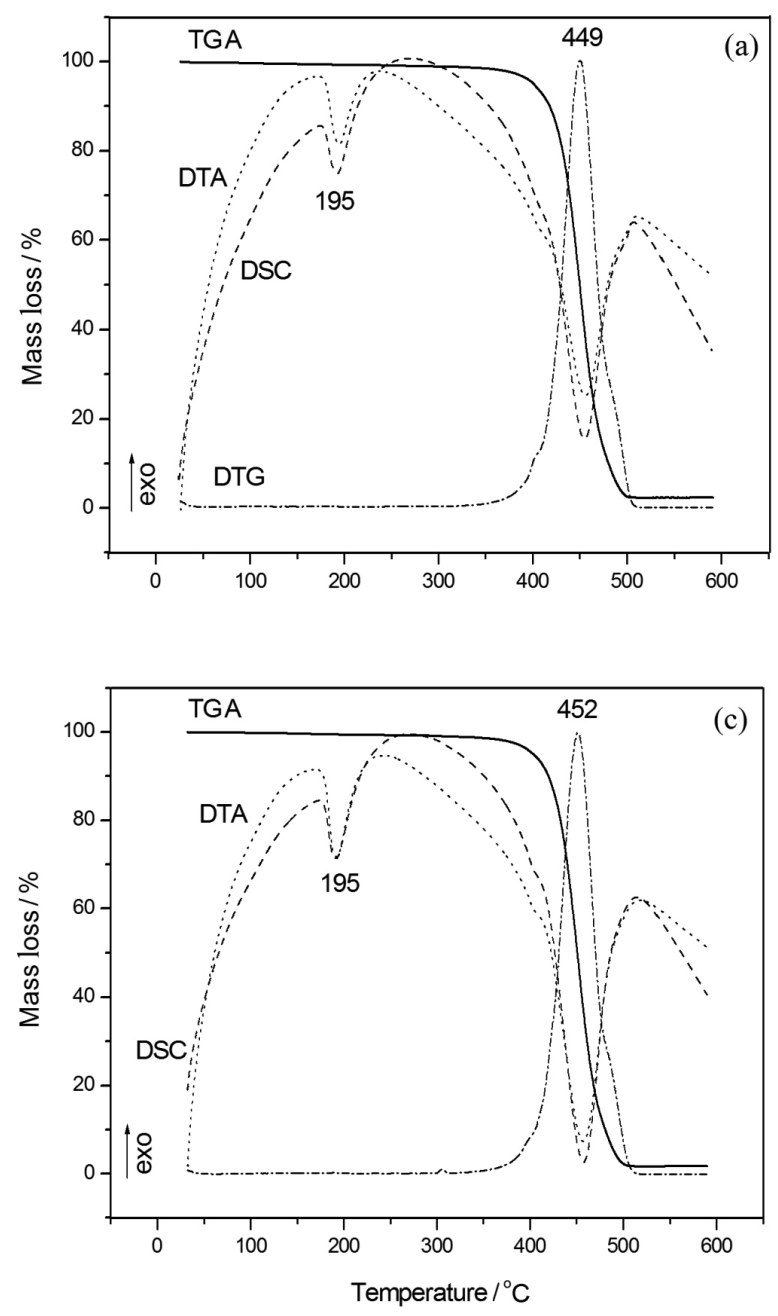

this period in SBF, and that the polymer network may have suffered some modification. The appearance of the bands at 364,328 and $320 \mathrm{~cm}^{-1}$ reveals that there is still PA-coating
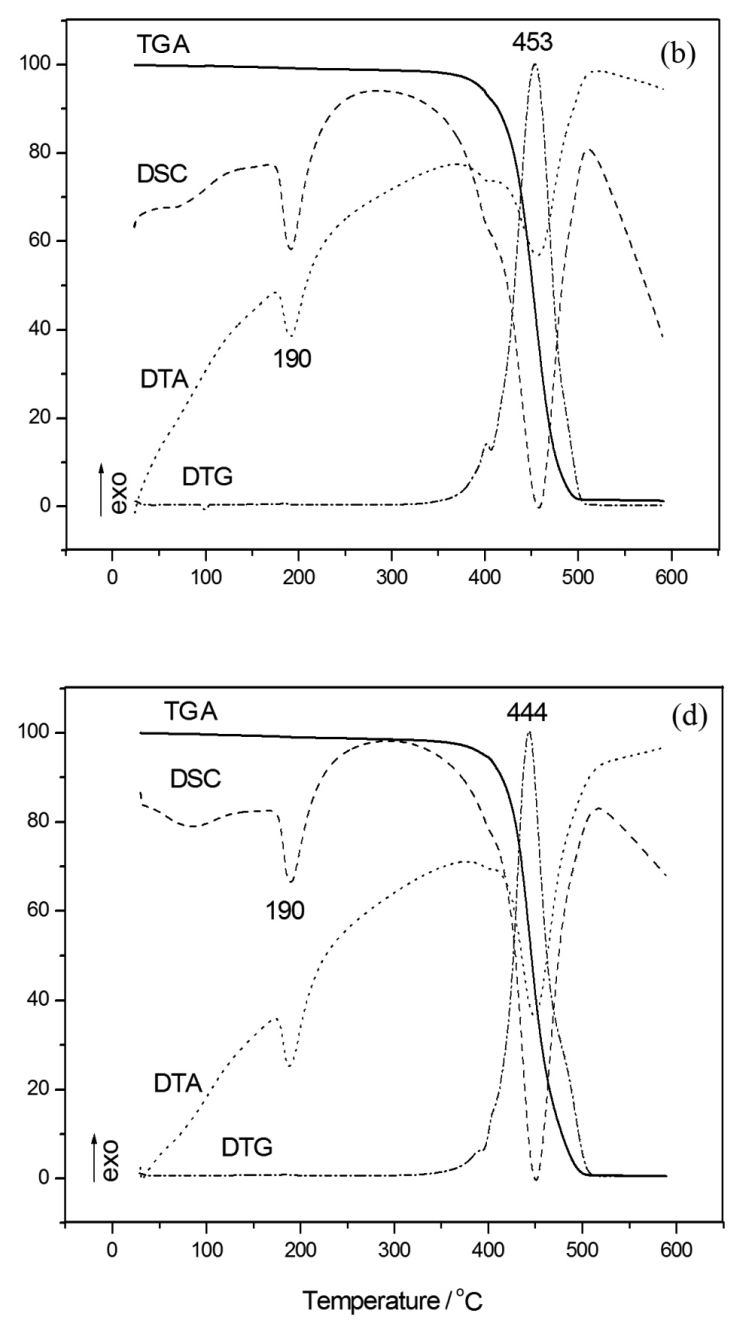

Figure 4. Thermal analysis of the NcP after 15 (a) and 30 (b) days in SBF and NsP after 15 (c) and 30 (d) days in SBF.
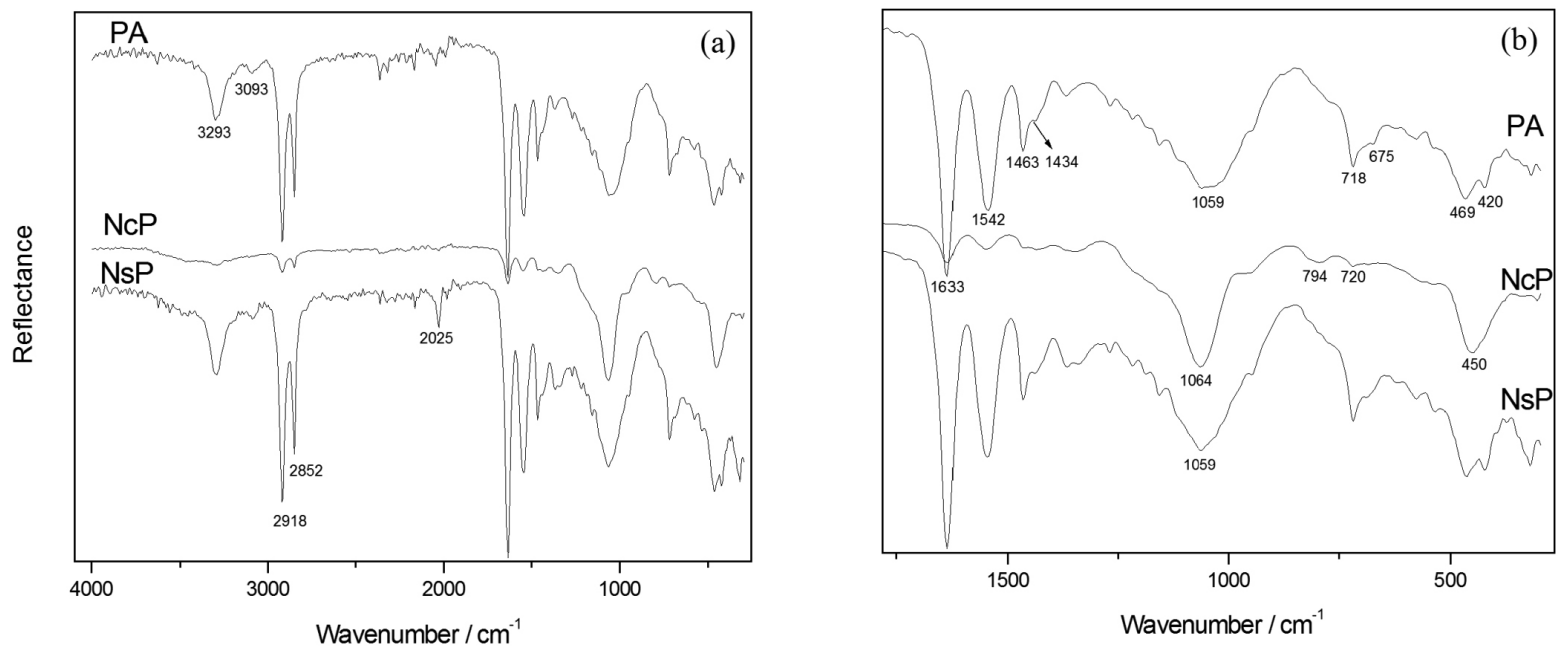

Figure 5. ATR-FTIR spectra of the PA, NcP and NsP. 
Table 1. Characteristic wavenumber for the samples PA, NcP and NsP before contact with the SBF solution

\begin{tabular}{lccc}
\hline Characteristic groups & PA & NcP & NsP \\
\hline N-H stretching vibration $/ \mathrm{cm}^{-1}$ & 3293 & 3299 & 3292 \\
N-H bending vibration / cm & 675 & 678 & 678 \\
$-\mathrm{CH}_{2}-$ stretching vibration $/ \mathrm{cm}^{-1}$ & 2913 & 2918 & 2818 \\
$-\mathrm{CH}-$ stretching vibration $/ \mathrm{cm}^{-1}$ & 2850 & 2852 & 2852 \\
\hline
\end{tabular}

interaction via the amide groups in the NcP sample. The band at $558 \mathrm{~cm}^{-1}$ present in the spectrum of $\mathrm{NcP}$ after 15 and 30 days in SBF indicates the formation of phosphate on the surface of the sample..$^{14,18}$

Figure $6 \mathrm{~b}$ depicts the ATR-FTIR spectra of the NsP sample before and after immersion in SBF. In this case, it can also be observed that the bands previously identified as being due to the interaction between the coating and the substrate undergo modifications. The bands at 1336 and $2025 \mathrm{~cm}^{-1}$ (ascribed to the amide groups) disappear when the NsP is immersed in SBF, suggesting changes in the initial PA-coating interaction. However, the presence of the bands attributed to amide groups of PA at 360, 336 and $310 \mathrm{~cm}^{-1}$ shows that a PA-coating interaction still exists. The shift of the band at $1062 \mathrm{~cm}^{-1}$ (assigned to $\mathrm{Si}-\mathrm{O}-\mathrm{Si}$ ) reveals that there were changes in the network

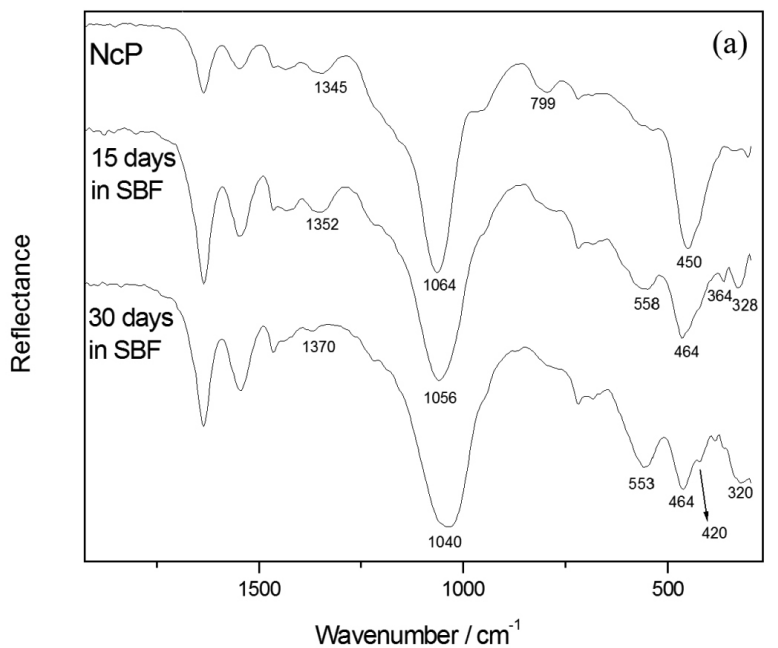

of the coating upon contact with SBF. After 30 days in SBF, bands attributed to crystalline phosphate ${ }^{14,18}$ can be detected at 602 and $560 \mathrm{~cm}^{-1}$ for the NsP sample. The phosphate crystal can be observed in the SEM micrographs (Figure 2).

The corresponding wavenumbers of the characteristic groups of PA in the coated substrate (namely samples $\mathrm{NcP}(15), \mathrm{NcP}(30), \mathrm{NsP}(15)$, and $\mathrm{NsP}(30)$ ) after contact with SBF solution for 15 and 30 days are listed in Table 2.

\section{Conclusion}

This work reports important results with respect to the coating on organic polymers carried out by the sol-gel process at low temperature. The PA structure here employed is not affected by the methodology used for the coating. The thermal resistance of the polymer increases because of the good adhesion of the coating onto PA.

The coating adherence can be ascribed to the chemical interaction taking place between the coating and the substrate, as demonstrated by FTIR analysis. In fact, the coating remains bound to the substrate even after contact with SBF solution for 30 days. Finally, although the coating is very thin, it is able to react with $\mathrm{SBF}$, promoting the formation of crystalline phosphate, thereby showing that

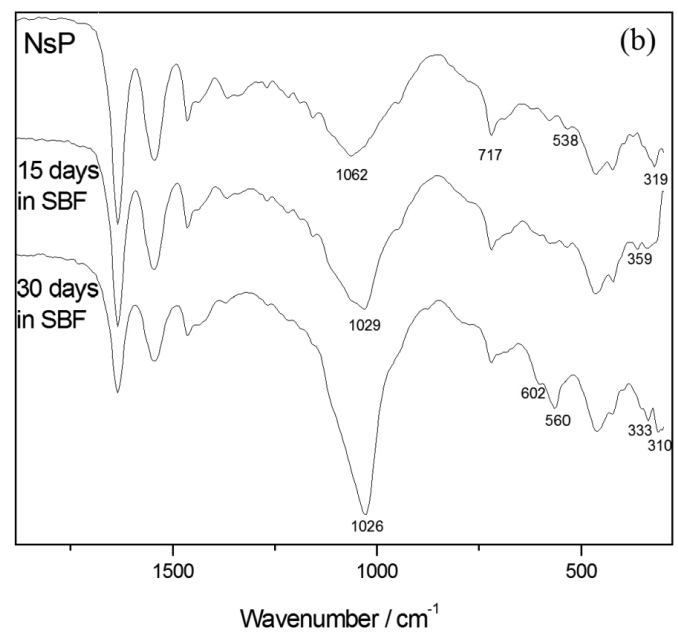

Figure 6. ATR-FTIR spectra of the $\mathrm{NcP}$ (a) and $\mathrm{NsP}$ (b) before and after contact with SBF.

Table 2. Characteristic wavenumbers for the samples $\mathrm{NcP}(15), \mathrm{NcP}(30), \mathrm{NsP}(15)$ and $\mathrm{NsP}(30)$ after contact with the $\mathrm{SBF}$ solution for 15 and 30 days

\begin{tabular}{lccc}
\hline Characteristic groups & NcP(15) & NcP(30) & NsP(30) \\
\hline N-H stretching vibration $/ \mathrm{cm}^{-1}$ & 3286 & 3286 & 3292 \\
N-H bending vibration $/ \mathrm{cm}^{-1}$ & 681 & 681 & 677 \\
$-\mathrm{CH}_{2}-$ stretching vibration $/ \mathrm{cm}^{-1}$ & 2919 & 2919 & 2918 \\
$-\mathrm{CH}-$ stretching vibration $/ \mathrm{cm}^{-1}$ & 2848 & 2848 & 2918 \\
$-\mathrm{PO}_{4}^{3-}$ & 558 & 553 & 2845 \\
\hline
\end{tabular}


the coated polymer here prepared is a potential candidate for application as biomaterial for bone replacement.

\section{Acknowledgments}

The authors acknowledge Fundação de Amparo à Pesquisa do Estado de São Paulo (FAPESP), Conselho Nacional de Desenvolvimento Científico e Tecnológico (CNPq) and Coordenação de Aperfeiçoamento de Pessoal de Nível Superior (CAPES) (Brazilian research funding agencies) for supporting this work.

\section{References}

1. Leeuwenburgh, S. C. G.; Malda, J.; Rouwkema, J.; Kirkpatrick, C. J.; Biomaterials 2008, 29, 3047.

2. Shen, J.; Li, Y.; Zuo, Y.; Zou, Q.; Li, J.; Huang, D.; Wang, X.; J. Biomed. Mater. Res., Part B 2009, 91, 897.

3. Wang, H.; Li, Y.; Zuo, Y.; Li, J.; Ma, S.; Cheng, L.; Biomaterials 2007, 28, 3338.

4. Jie, W.; Yubao, L.; Eur. Polym. J. 2004, 40, 509.

5. Zhang, Y.; Hao, L.; Savalani, M. M.; Harris, R. A.; Di Silvio, L.; Tanner, K. E.; J. Biomed. Mater. Res., Part A 2009, 91, 1018.

6. Salmoria, G. V.; Leite, J. L.; Paggi, R. A.; Polym. Test. 2009 , 28,746 .

7. Volpato, N.; Prototipagem Rápida: Tecnologias e Aplicações; Edgard Blücher: São Paulo, Brasil, 2007.

8. Meurer, M. I.; Nobre, L. F. S.; Meurer, E.; Silva, J. V. L.; Santa Bárbara, A.; Oliveira, M. G.; Silva, D. N.; Santos, A. M. B. In Virtual Modelling and Rapid Manufacturing; Bártolo, P. J.; Batista, F. C., eds.; Taylor \& Francis Group: London, 2005, p. 167.

9. Nassar, E. J.; Avila, L. R.; Pereira, P. F. S.; Nassor, E. C. O.; Cestari, A.; Ciuffi, K. J.; Calefi, P. S.; Quim. Nova 2007, 30, 1567.

10. Cestari, A.; Bandeira, L. C.; Calefi, P. S.; Nassar, E. J.; Ciuffi, K. J.; J. Alloys Compd. 2009, 472, 299.

11. Nassar, E. J.; Nassor, E. C. O.; Avila, L. R.; Pereira, P. F. S.; Cestari, A.; Luz, L. M.; Ciuffi, K. J.; Calefi, P. S.; J. Sol-Gel Sci. Technol. 2007, 43, 21.

12. Rocha, L. A.; Molina, E. F.; Ciuffi, K. J.; Calefi, P. S.; Nassar, E. J.; Mater. Chem. Phys. 2007, 101, 238.

13. Arcos, D.; Vallet-Regí, M.; Acta Biomater. 2010, 6, 2874.

14. Peitl, O.; Zanotto, E. D.; Hench, L. L.; J. Non-Cryst. Solids 2001, 292, 115.
15. Hench, L. L.; Sol-Gel Silica: Properties, Processing and Technology Transfer; Noyes Publications: London, 1998.

16. Wright, J. D.; Sommerdijk, N. A. J. M.; Sol-Gel Materials Chemistry and Applications, vol. 4; Gordon and Breach Science Publishers: Amsterdam, 2001.

17. Aegerter, M. A.; Menning, M.; Sol-Gel Technologies for Glass Producers and Users; Kluwer Academic Publishers: U.S.A., 2004.

18. Takadama, H.; Kim, H.-M.; Kokubo, T.; Nakamura, T.; Chem. Mater. 2001, 13, 1108.

19. Kawai, T.; Ohtsuki, C.; Kamitakahara, M.; Hosoya, K.; Tanihara, M.; Miyazaki, T.; Sakaguchi, Y.; Konagaya, S.; J. Mater. Sci.: Mater. Med. 2007, 18, 1037.

20. Kawaia, T.; Ohtsukia, C.; Kamitakaharaa, M.; Miyazakib, T.; Taniharaa, M.; Sakaguchic, Y.; Konagay, S.; Biomaterials 2004, $25,4529$.

21. Nassar, E. J.; Ciuffi, K. J.; Gonçalves, R. R.; Messaddeq, Y.; Ribeiro, S. J. L.; Quim. Nova 2003, 26, 674.

22. Bandeira, L. C.; De Campos, B. M.; De Faria, E. H.; Ciuffi, K. J.; Calefi, P. S.; Nassar, E. J.; Silva, J. V. L.; Oliveira, M. F.; Maia, I. A.; J. Therm. Anal. Calorim. 2009, 97, 67.

23. de Campos, B. M.; Bandeira, L. C.; Calefi, P. S.; Ciuffi, K. J.; Nassar, E. J.; Silva, J. V. L.; Oliveira, M.; Maia, I. A.; Virt. Phys. Prototyping 2011, 6, 33.

24. Kokubo, T.; Kushitani, H.; Sakka, S.; Kitsugi, T.; Yamamuro, T.; J. Biomed. Mater. Res. 1990, 24, 721.

25. Yi, Z.; Yubao, L.; Jidong, L.; Xiang, Z.; Hongbing, L.; Yuanyuan, W.; Weihu, Y.; Mater. Sci. Eng., A 2007, 452/453, 512.

26. Jie, W.; Yubao, L.; Yi, H.; J. Mater. Sci. 2005, 40, 793.

27. Bandeira, L. C.; Ciuffi, K. J.; Calefi, P. S.; Nassar, E. J.; Adv. Biosci. Biotechnol. 2010, 1, 200.

28. Bandeira, L. C.; Calefi, P. S.; Ciuffi, K. J.; Nassar, E. J.; Salvado, I. M. M.; Fernandes, M. H. F. V.; Cerâmica 2011, 57, 166.

29. Zhang, X.; Li, Y.-B.; Zuo, Y.; Li, G.-Y.; Mu, Y.-H.; Li, H.; Composites Part A 2007, 38, 843.

30. Bueno, W. A.; Manual de Espectroscopia Vibracional; McGrawHill: São Paulo, Brasil, 1989.

31. Colthup, N. B.; Daly, L. H.; Wiberley, S. E.; Introduction to Infrared and Raman Spectroscopy; Academic Press: San Diego, 1990.

Submitted: October 24, 2011

Published online: March 27, 2012

FAPESP has sponsored the publication of this article. 